\title{
Lipase-Catalyzed Production of Sorbitol Laurate in a "2-in-1" Deep Eutectic System: Factors Affecting the Synthesis and Scalability
}

\author{
André Delavault ${ }^{1, *(D)}$, Oleksandra Opochenska ${ }^{1}$, Laura Laneque ${ }^{1}$, Hannah Soergel ${ }^{2}$, Claudia Muhle-Goll ${ }^{2}$, \\ Katrin Ochsenreither ${ }^{1}$ (D) and Christoph Syldatk ${ }^{1}$ \\ 1 Technical Biology, Institute of Process Engineering in Life Sciences II, Karlsruhe Institute of Technology, \\ 76131 Karlsruhe, Germany; o.opochenska@gmail.com (O.O.); laura.laneque@gmail.com (L.L.); \\ katrin.ochsenreither@kit.edu (K.O.); christoph.syldatk@kit.edu (C.S.) \\ 2 Institute for Biological Interfaces 4 and Institute of Organic Chemistry, Karlsruhe Institute of Technology, \\ 76021 Karlsruhe, Germany; hannah.soergel@kit.edu (H.S.); claudia.muhle-goll@kit.edu (C.M.-G.) \\ * Correspondence: andre.delavault@kit.edu; Tel.: +49-721-60846739
}

check for updates

Citation: Delavault, A.; Opochenska, O.; Laneque, L.; Soergel, H.; Muhle-Goll, C.; Ochsenreither, K.; Syldatk, C. Lipase-Catalyzed Production of Sorbitol Laurate in a "2-in-1" Deep Eutectic System: Factors Affecting the Synthesis and Scalability. Molecules 2021, 26, 2759. https:// doi.org/10.3390/molecules26092759

Academic Editor: Rafał M. Łukasik

Received: 21 April 2021

Accepted: 6 May 2021

Published: 7 May 2021

Publisher's Note: MDPI stays neutral with regard to jurisdictional claims in published maps and institutional affiliations.

Copyright: (c) 2021 by the authors. Licensee MDPI, Basel, Switzerland. This article is an open access article distributed under the terms and conditions of the Creative Commons Attribution (CC BY) license (https:/ / creativecommons.org/licenses/by/ $4.0 /)$.

\begin{abstract}
Surfactants, such as glycolipids, are specialty compounds that can be encountered daily in cleaning agents, pharmaceuticals or even in food. Due to their wide range of applications and, more notably, their presence in hygiene products, the demand is continuously increasing worldwide. The established chemical synthesis of glycolipids presents several disadvantages, such as lack of specificity and selectivity. Moreover, the solubility of polyols, such as sugars or sugar alcohols, in organic solvents is rather low. The enzymatic synthesis of these compounds is, however, possible in nearly water-free media using inexpensive and renewable building blocks. Using lipases, ester formation can be achieved under mild conditions. We propose, herein, a "2-in-1" system that overcomes solubility problems, as a Deep Eutectic System (DES) made of sorbitol and choline chloride replaces either a purely organic or aqueous medium. For the first time, 16 commercially available lipase formulations were compared, and the factors affecting the conversion were investigated to optimize this process, owing to a newly developed High-Performance Liquid ChromatographyEvaporative Light Scattering Detector (HPLC-ELSD) method for quantification. Thus, using $50 \mathrm{~g} / \mathrm{L}$ of lipase formulation Novozym $435^{\circledR}$ at $50{ }^{\circ} \mathrm{C}$, the optimized synthesis of sorbitol laurate (SL) allowed to achieve $28 \%$ molar conversion of $0.5 \mathrm{M}$ of vinyl laurate to its sugar alcohol monoester when the DES contained $5 \mathrm{wt}$ \% w water. After $48 \mathrm{~h}$, the de novo synthesized glycolipid was separated from the media by liquid-liquid extraction, purified by flash-chromatography and characterized thoroughly by one- and two-dimensional Nuclear Magnetic Resonance (NMR) experiments combined to Mass Spectrometry (MS). In completion, we provide initial proof of scalability for this process. Using a $2.5 \mathrm{~L}$ stirred tank reactor (STR) allowed a batch production reaching $25 \mathrm{~g} / \mathrm{L}$ in a highly viscous two-phase system.
\end{abstract}

Keywords: glycolipid; sugar alcohol; ester; biosynthesis; optimization; unconventional media

\section{Introduction}

Glycolipids and, more generally, surfactants are getting more attention and are currently under scrutiny from the scientific community because of their various fields of applications [1]. This versatility allows them to fill different functions, such as excipient in drugs, encapsulating agents, lubricants and many more [2]. Such quasi-omnipresence makes their use valuable in very concrete and industrialized applications such as oil recovery enhancement or even as dough conditioning [3,4]. Moreover, the recent sanitary crisis, which resulted from the current global pandemic, is announced to increase further this production, as surfactants are among the main components present in hygiene products [5]. Thus, the whole chain of production starting from the acquisition of raw materials to 
the formulation and storage should be logically stimulated as well. Given the context, it appears topical to develop processes that enable safe, reliable and straightforward production of such compounds. In addition, the processes and the resulting compounds should respond to present concerns in relation to sustainability, renewability, and biodegradability. Such problems brought to awareness and theorized by the Green Chemistry field revolve around the "benign by design" concept [6]. By definition, it means that chemical products and processes should be designed to eliminate the generation of hazardous substances [7]. Therefore, it reduces the number of steps necessary for the production, from the synthesis to the downstream processing (DSP), and simplifies the overall process chain.

Glycolipids, such as sugar esters (SEs), are, in this regard, relevant candidates that meet the aforementioned requirements; several challenges and problems are raising in the meantime, which are tackled in this work.

The well-established chemical production of SEs presents several disadvantages and limitations such as low specificity, low selectivity and use of corrosive reactants [8]. Consequently, alternative ways were pursued to prevent the use of organic solvents, as they represent most of the waste in industrial processes and syntheses [9]. Moreover, they present undeniable limitations for the solubilization of polyols such as sugars. In this aim, the production of SEs in ionic liquids (ILs) [10] and in Deep Eutectic Systems (DESs) [11] were investigated. The latter, described first by Abbott et al., represents a cheaper, less toxic, and facile option among the low-transition temperature mixtures [12]. Additionally, their low water contents and low water activities lead lipases to reverse their activity and form ester bonds using relatively mild and harmless conditions [13].

Numerous applications of DESs in environmentally friendly chemical processes have been made, notably for the production of pharmaceutically relevant building blocks and scaffolds [14-16]. Moreover, DESs can also be used for the extraction of valuable compounds such as phenolics contained in olive oil wastes [17], adding them as a sustainable tool for food waste treatment and re-valorization. In our similar and inherently benign approach, sorbitol is simultaneously part of the solvent as a DES partner, in combination with choline chloride, and part of the lipase-catalyzed reaction as a substrate. Intrinsically, this reaction design solves solubility problems of the polyols while saturating the system with the acyl acceptor. This "2-in-1" principle described first by Siebenhaller et al. [18], using notably $\mathrm{C} 4$ to $\mathrm{C} 6$ sugars in combination with vinyl fatty esters, presented however exceptionally low yields $(\sim 4 \%)$ and lacked proof of scalability [19]. The use of vinyl esters for SE synthesis, described by Bornscheuer et al., is thermodynamically favored as the vinyl adduct is converted during the reaction to the side-product ethenol, which itself tautomerizes in the highly volatile acetaldehyde [20] (Figure 1). For the first time, we enhanced further the conversion yield of this advantageous system, using a relatively better acyl acceptor for the reaction [21]. Indeed, sorbitol and, more generally sugar alcohols, showed successful use in prior research as they are also less sensitive to degradation than their actual sugar analogues [22-25]. Moreover, laurate monoesters are valuable for many recently developed applications such as drug encapsulation [26].

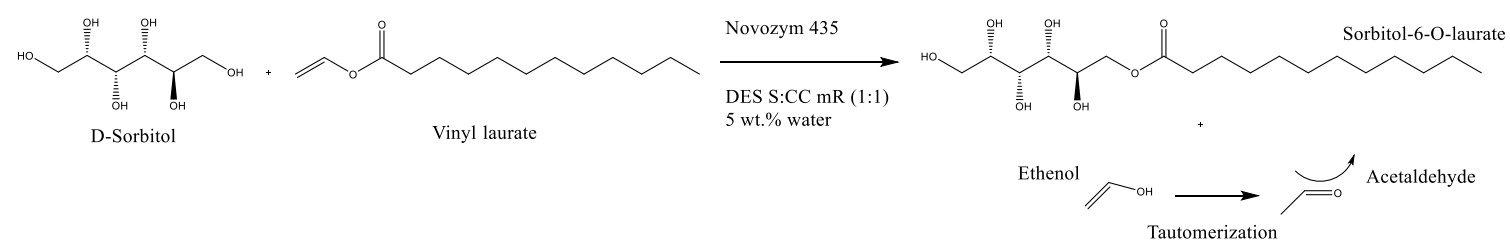

Figure 1. Lipase-catalyzed transesterification reaction between D-sorbitol and vinyl laurate. Evaporation of highly volatile acetaldehyde makes the conversion irreversible. S: Sorbitol; CC: Choline Chloride; mR: molar Ratio.

We initiated, herein, the optimization of the " 2 -in-1" process by selecting Novozym $435^{\circledR}$ as a suitable biocatalyst among various commercially available lipase formulations and sought, specifically to our system, its optimal performing parameters. We varied 
parameters (One-Factor-at-a-Time, OFaaT) one at a time, such as biocatalyst concentration, time of reaction, substrate concentration and water content. The optimal temperature for the use of this specific lipase has been extensively studied in literature. Moreover, previous work from Siebenhaller et al. [27] and Hollenbach et al. [28] presented concomitantly that in the range of $50-60^{\circ} \mathrm{C}$, the enzyme meets its optimal activation energy.

In addition, we present robust purification and identification strategies promoted by suitable analytical but also flash-chromatography methods for the quantification and preparative scale ( $>500 \mathrm{~g}$ ) production of sorbitol-6-O-laurate using a batch stirred tank reactor (STR). The successful investigation was insured by the use of relevant Evaporative Light Scattering Detection (ELSD) combined with HPLC and flash-chromatography. Thus, the production of pure standards enabled the establishment of the calibration curve and the 1D-, 2D-Nuclear Magnetic Resonance (NMR) and Mass Spectrometry (MS) characterization of selectively-acylated sorbitol monolaurate.

\section{Results}

In the following sections, we report the investigation of commercially available lipase formulations to produce SL alongside a newly developed quantification method that allowed the investigation of the impact of several synthesis factors. Following the product formation over time also allowed optimization of reaction time, enzyme and substrate concentration and subsequently, the water content of the DES. Finally, the titer of the optimized process, as well as proof of scalability and technical notes for the use of a batch STR followed by the DSP procedure, are presented.

\subsection{Sorbitol Monolaurate (SL) Quantification}

We, herein, successfully separated and quantified SL using a newly developed analytical HPLC-ESLD method, which allowed the differentiation of the products and substrates (Supplementary Materials Figure S1). Sorbitol had a retention time of $2.1 \mathrm{~min}, 3.1 \mathrm{~min}$ for SL and $~ 9.5$ min for lauric acid (not integrated). Due to the low baseline noise and suitable peak resolution (Table 1), it was possible to quantify SL in a range between $0.75 \mathrm{~g} / \mathrm{L}$ and $30 \mathrm{~g} / \mathrm{L}$ with the use of two linear ranges of calibration as ELSD does not provide a linear response when analyte concentration increased.

Table 1. Chromatographic and analytical characteristics of SL analysis using HPLC-ESLD.

\begin{tabular}{|c|c|}
\hline Retention time (SL) * & $3.55-3.59 \mathrm{~min}$ \\
\hline Peak width ** & $0.060-0.091 \mathrm{~min}$ \\
\hline Resolution $_{\text {sorbitol—SL }}(n=3)$ & 17.5 \\
\hline Resolution $_{\text {SL-lauric acid }}(n=3)$ & 7.6 \\
\hline Baseline noise $(n=3)$ & $0.22 \pm 0.07 \mathrm{mV}$ \\
\hline Limit of detection $($ signal $/$ noise $=3$ ) & $<0.04 \mathrm{~g} / \mathrm{L}$ \\
\hline Limit of quantification $($ signal $/$ noise $=10)$ & $0.04 \mathrm{~g} / \mathrm{L}$ \\
\hline \multicolumn{2}{|c|}{ 1st Range of Linear Calibration } \\
\hline Correlation coefficient $\left(\mathrm{R}^{2}, n=3\right)$ & 0.9967 \\
\hline Equation of linear calibration & $y=0.001 x+0.988$ \\
\hline Linear range of calibration & $0.75-15 \mathrm{~g} / \mathrm{L}$ \\
\hline \multicolumn{2}{|c|}{ 2nd Range of Linear Calibration } \\
\hline Correlation coefficient $\left(\mathrm{R}^{2}, n=3\right)$ & 0.9993 \\
\hline Equation of linear calibration & $y=0.002 x-21.639$ \\
\hline Linear range of calibration & $20-30 \mathrm{~g} / \mathrm{L}$ \\
\hline
\end{tabular}

* Inter-day variance of retention time measured at 3 different days. ${ }^{* *}$ Concentration $0.75-30 \mathrm{~g} / \mathrm{L}$.

\subsection{Commercially Available Formulations Screening}

Figure 2 shows that the highest yields of vinyl laurate conversion into SL were obtained by Lipase B from Candida antarctica (CA) formulations such as Novozym $435^{\circledR}$, Lipozyme $435^{\circledR}$ and Lipozyme CALB L (liquid formulation). Regardless of the applied form, all of them seem to reach statistically equivalent results of $\sim 20 \%$ under non-optimized 
reaction conditions. However, it is important to note that liquid formulations potentially contain more catalytic material than the immobilized ones, showing the limitations of our comparison.

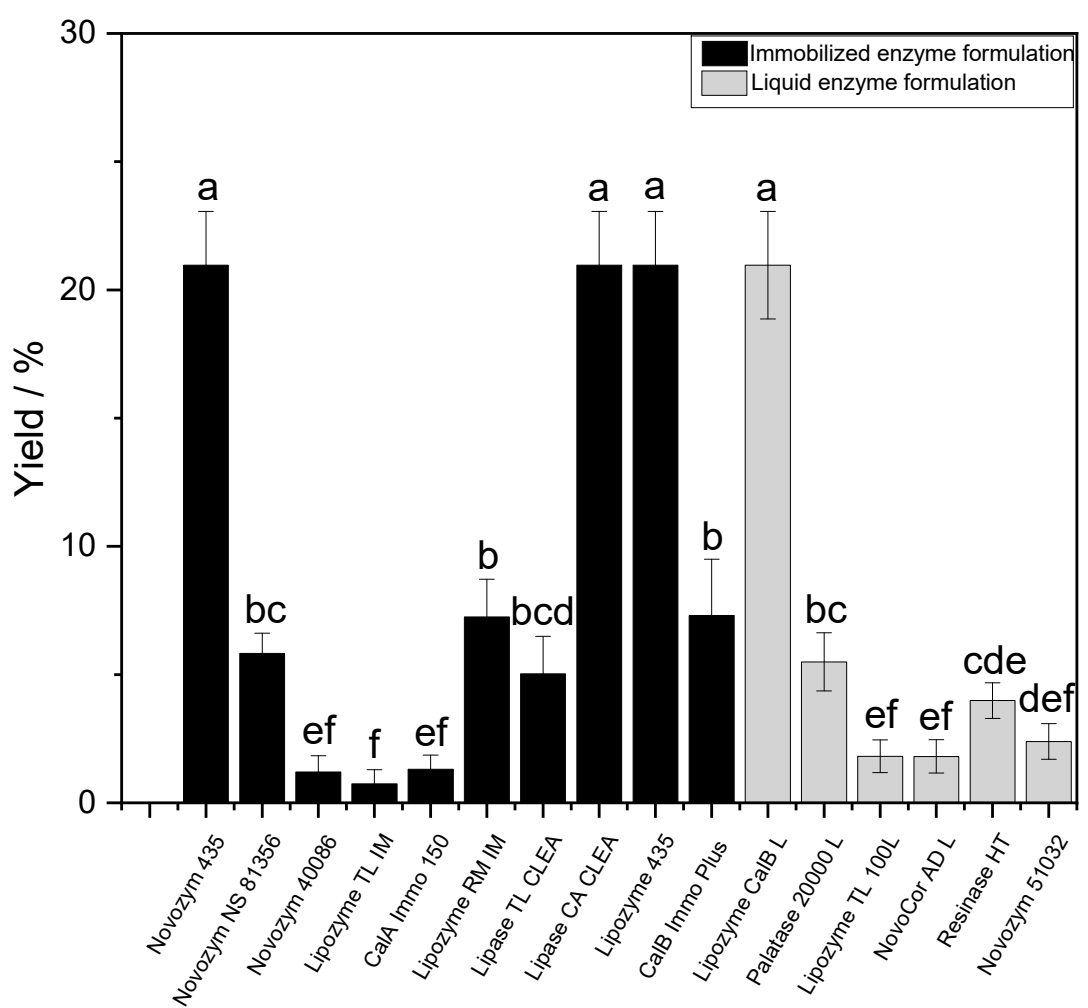

Figure 2. Comparison of SL conversion yields calculated from $0.5 \mathrm{M}$ vinyl laurate. A triplicate was done for each screened commercially available formulation after $48 \mathrm{~h}$ at $50{ }^{\circ} \mathrm{C}$. a-f show statistically significant differences $(p<0.05)$.

As we compare these lipase formulations on the basis of applied concentrations $(20 \mathrm{~g} / \mathrm{L})$, the quantity of actual enzyme present in the reaction most likely differs; moreover, very little data on the matter are made available by the producers. However, the quantity of enzyme is directly linked to the amount of formulation used; thus, when comparing immobilized enzymes, this variable is intrinsically highlighted. As a result, we are, among other factors, comparing qualitatively the immobilization efficiency of the various formulations tested. In this aim and in our system, either using the food-grade formulation (Lipozyme $435^{\circledR}$ ) or the technical grade one (Novozym $435^{\circledR}$ ) did not lead to significant differences in titer after $48 \mathrm{~h}$ of reaction (Table 2). Interestingly the Cross-Linked Enzyme Aggregate (CLEA) from CA seemed to reach statistically similar levels of performance. Therefore, in the following sections, we chose to report the influence of several factors affecting our system. For this purpose, we used Novozym $435^{\circledR}$ as the archetype of the commercially available lipase formulation for SE synthesis. As a first step, we decided to investigate the evolution of SL titer over time.

\subsection{Product Formation over Time}

To determine the optimal reaction time to produce the maximum amount of SL, the concentration of produced glycolipid was recorded over $96 \mathrm{~h}$. Thus, we reached a saturation of product after $48 \mathrm{~h}$ with apparently no significant changes in concentration, even up to $96 \mathrm{~h}$ of reaction, as shown in Figure 3. 
Table 2. Titer ( $\mathrm{g} / \mathrm{L}$ ) of SL obtained after $48 \mathrm{~h}$ with commercially available enzyme formulations.

\begin{tabular}{ccccc}
\hline Formulation Name & Reported Activity * & Formulation Type & $\begin{array}{c}\text { Reported Optimal } \\
\text { Temperature Range }\left({ }^{\circ} \mathbf{C}\right) *\end{array}$ & Titer (g/L) $* *$ \\
\hline CalA Immo 150 & $500 \mathrm{U} / \mathrm{g}$ & Immobilized & N.C. & $2.3 \pm 0.9$ \\
CalB Immo Plus & $>9000 \mathrm{PLU} / \mathrm{g}$ & Immobilized & $60-80$ & $13.3 \pm 3.0$ \\
Lipase CA CLEA & $>1.5 \mathrm{U} / \mathrm{mg}$ & Cross-linked & $>40$ & $38.2 \pm 3.8$ \\
Lipase TL CLEA & $\geq 25 \mathrm{U} / \mathrm{mg}$ & Cross-linked & $40-60$ & $9.2 \pm 2.7$ \\
Lipozym 435 & $9000 \mathrm{PLU} / \mathrm{g}$ & Immobilized & $\mathrm{N} . \mathrm{C}$. & $38.2 \pm 3.8$ \\
Lipozyme CALB L & $5000 \mathrm{LU} / \mathrm{g}$ & Liquid & $30-60$ & $38.2 \pm 3.8$ \\
Lipozyme RM IM & $275 \mathrm{IUN} / \mathrm{g}$ & Immobilized & $30-50$ & $13.2 \pm 2.7$ \\
Lipozyme TL 100L & $100 \mathrm{KLU} / \mathrm{g}$ & Liquid & $20-50$ & $3.3 \pm 1.2$ \\
Lipozyme TL IM & $250 \mathrm{IUN} / \mathrm{g}$ & Immobilized & $50-75$ & $1.3 \pm 1.0$ \\
NovoCor AD L & $6000 \mathrm{LU} / \mathrm{g}$ & Liquid & $30-60$ & $3.3 \pm 1.2$ \\
Novozym 40086 & $275 \mathrm{IUN} / \mathrm{g}$ & Immobilized & $30-50$ & $3.2 \pm 1.1$ \\
Novozym 435 & $10,000 \mathrm{PLU} / \mathrm{g}$ & Immobilized & $30-60$ & $38.2 \pm 3.8$ \\
Novozym 51032 & $15 \mathrm{KLU} / \mathrm{g}$ & Liquid & $35-70$ & $4.4 \pm 1.3$ \\
Novozym NS 81356 & $\mathrm{N} . \mathrm{C}$. & Immobilized & N.C. & $10.6 \pm 1.4$ \\
Palatase 20000 L & $20,000 \mathrm{LU} / \mathrm{g}$ & Liquid & $30-50$ & $\leq .0 \pm 2.1$ \\
Resinase HT & $50 \mathrm{KLU} / \mathrm{g}$ & Liquid & $\leq 90$ & $7.3 \pm 1.3$ \\
\hline
\end{tabular}

N.C.: Not Communicated. ${ }^{*}$ Reported data are provided by the producers and are available online. ${ }^{* *}$ Experiments were performed as triplicates under identical conditions: $0.5 \mathrm{M}$ of vinyl laurate and $20 \mathrm{mg}$ of formulation in $1.5 \mathrm{~mL}$ of Sorbit DES (sorbitol/choline chloride, $1: 1, \mathrm{mR}, 5 \mathrm{wt} . \%$ water $)$ after $48 \mathrm{~h}$ at $50^{\circ} \mathrm{C}$. Data is presented as mean values \pm standard deviations $(n=3, p$-value $<0.05)$.

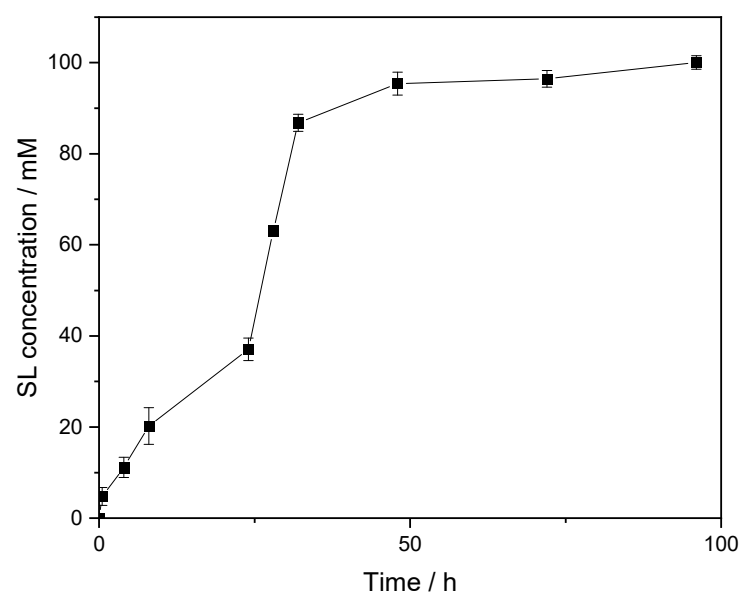

Figure 3. Time course of the reaction under unoptimized conditions: $0.5 \mathrm{M}$ of vinyl laurate, $20 \mathrm{mg}$ of Novozym $435^{\circledR}$ and $1.5 \mathrm{~mL}$ of Sorbit DES as solvent (sorbitol/choline chloride, 1:1, mR, $5 \mathrm{wt} . \%$ water) at $50{ }^{\circ} \mathrm{C}$.

Under these unoptimized conditions using Novozym $435^{\circledR}$, a concentration of $95 \pm 2.5 \mathrm{mM}$ of the product was obtained after $48 \mathrm{~h}$ of reaction, which translates to specific productivity of $100 \mu \mathrm{mol} / \mathrm{h} / \mathrm{g}$. Until now, no data has been reported regarding the use of a "2-in-1" DES system for lipase-catalyzed transesterification between a vinyl laurate and sorbitol in order to synthetize such monoacylated sugar alcohol ester.

\subsection{Effect of Enzyme, Substrate and Water Contents}

Herein, Novozym $435^{\circledR}$ was used as the biocatalyst for the reaction that was carried out in the "2-in-1" Sorbit DES. Factors impacting the reaction (i.e., enzyme concentration, enzyme dosage and water content in the media) have been investigated to find the optimal parameters for each condition. From Figure 4, it can be discerned that the optimal values were $50 \mathrm{~g} / \mathrm{L}$ enzyme, $0.5 \mathrm{M}$ vinyl laurate and $5 \mathrm{wt} \%$ water. 

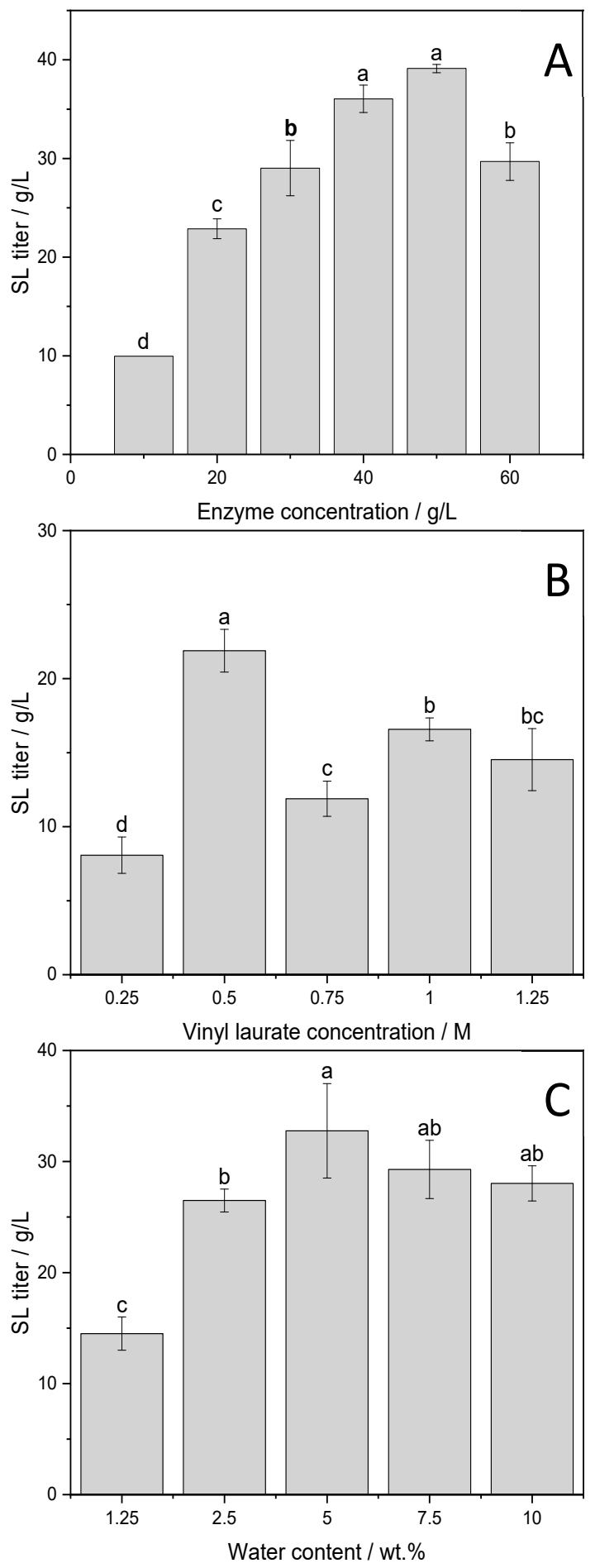

Figure 4. Novozym $435^{\circledR}$-catalyzed transesterification of sorbitol and vinyl laurate in "2-in-1" Sorbit deep eutectic system: Effect of enzyme dosage (A); vinyl laurate concentration (B); water content in the media (C) on the titer after $48 \mathrm{~h}$. a-d show statistically significant differences, at a 0.05 significance level, of the mean values obtained from three independent experiments ran under each condition.

Statistical analysis of the different titers reached after $48 \mathrm{~h}$ in relation to enzyme concentration revealed significant differences when the amount of enzyme was at least doubled from the $20 \mathrm{~g}$ /L starting point (Figure 4A). Drastic differences can be observed in Figure 4B, as $0.5 \mathrm{M}$ of vinyl laurate induces a two-fold increase in titer compared to $0.25 \mathrm{M}$ and $0.75 \mathrm{M}$. This safely suggests that upon a range of concentration $>0.5 \mathrm{M}$, there 
was potentially an inhibition of the biocatalyst due to substrate saturation. Above this concentration and in spite of the statistical analysis, comparisons are rendered ambiguous considering the lack of trend and should be interpreted with a certain distance. The results displayed in Figure 4C are rather more ambiguous as well, concerning the water content. Indeed, above $5 \mathrm{wt} . \%$ water, it seems that an optimal range of water content was reached. Overall, the results tend to indicate that enzyme and substrate concentrations were predominant factors compared to the water content, to some extent, as the Sorbit DES with a $2.5 \mathrm{wt} . \%$ water content ultimately limits the conversion most probably due to its measured 2-fold higher viscosity (Table A1). It also seems that the Sorbit DES with 5 wt.\% water provides the optimal $\mathrm{A}_{\mathrm{W}}$ for the enzymatic activity ( 0.08). Thus, a compromise has been found on the water content of the Sorbit DES, giving a good balance between viscosity and water activity for an optimal substrate conversion. In the following section, we display the structural elucidation of the product and the impact of the optimized combined factors on our process.

\subsection{Structural Elucidation Using Spectroscopic and Spectrometric Methods}

Here, we report one of the most extensive structural characterizations of $\mathrm{SL} .{ }^{1} \mathrm{H}$ - and ${ }^{13} \mathrm{C}-$ Nuclear Magnetic Resonance (NMR) Spectroscopy and Mass Spectrometry (MS) were performed on the purified compound. Additional ${ }^{1} \mathrm{H}-{ }^{1} \mathrm{H}$ COSY and ${ }^{1} \mathrm{H}-{ }^{1} \mathrm{H}$ TOCSY, ${ }^{1} \mathrm{H}-{ }^{13} \mathrm{C}$ HSQC and ${ }^{1} \mathrm{H}_{-}{ }^{13} \mathrm{C}$ HMBC (Supplementary Materials, Figures S2-S5) combined with MS results, confirmed that only one acyl group (laurate adduct) was bound to a primary hydroxyl group of sorbitol. From the 1D- and 2D-NMR experiments, the chemical shifts and their assignments are fully detailed in Table 3.

Table 3. ${ }^{1} \mathrm{H}$ - and ${ }^{13} \mathrm{C}-\mathrm{NMR}$ chemical shifts of sorbitol-6-O-laurate (SL) with their molecular assignments.

\begin{tabular}{|c|c|c|c|c|}
\hline Molecular Group & ${ }^{13}$ C Shift (ppm) & ${ }^{1} \mathrm{H}$ Shift (ppm) & Multiplicity & Coupling $(\mathrm{Hz})$ \\
\hline \multicolumn{5}{|l|}{ Sorbitol } \\
\hline$-\mathrm{C}^{1} \mathrm{H}_{2}-\mathrm{O}-*$ & 66.66 & $4.35,4.18$ & $\mathrm{dd}, \mathrm{dd}$ & $3.0,11.5,6.3$ \\
\hline$-\mathrm{C}^{2} \mathrm{H}-$ & 70.69 & 3.91 & $\mathrm{~m}$ & - \\
\hline$-\mathrm{C}^{3} \mathrm{H}-$ & 73.24 & 3.68 & $\mathrm{dd}$ & $5.28,7.37$ \\
\hline$-\mathrm{C}^{4} \mathrm{H}-$ & 70.27 & 3.93 & $\mathrm{t}$ & 4.84 \\
\hline$-\mathrm{C}^{5} \mathrm{H}-$ & 74.32 & 3.83 & $\mathrm{~m}$ & - \\
\hline $\mathrm{OH}-\mathrm{C}^{6} \mathrm{H}_{2-}$ & 64.25 & 3.71 & $\mathrm{~m}$ & - \\
\hline \multicolumn{5}{|l|}{ Laurate } \\
\hline $\mathrm{O}=\mathrm{C}^{1}-\mathrm{OH}$ * & 174.46 & - & - & - \\
\hline$-\mathrm{C}^{2} \mathrm{H}_{2^{-}}{ }^{*}$ & 34.64 & 2.33 & $\mathrm{t}$ & 7.6 \\
\hline$-\mathrm{C}^{3} \mathrm{H}_{2-}^{-}$ & 25.46 & 1.61 & $\mathrm{~m}$ & - \\
\hline$-\mathrm{C}^{4} \mathrm{H}_{2-}^{-}$ & 29.72 & 1.32 & $\mathrm{~m}$ & - \\
\hline$-\mathrm{C}^{5} \mathrm{H}_{2-}^{-}$ & 30.12 & 1.28 & $\mathrm{~m}$ & - \\
\hline$-\mathrm{C}^{6} \mathrm{H}_{2-}^{-}$ & 30.12 & 1.28 & $\mathrm{~m}$ & - \\
\hline$-\mathrm{C}^{7} \mathrm{H}_{2-}^{-}$ & 30.12 & 1.28 & $\mathrm{~m}$ & - \\
\hline$-\mathrm{C}^{8} \mathrm{H}_{2-}^{-}$ & 30.12 & 1.28 & $\mathrm{~m}$ & - \\
\hline$-\mathrm{C}^{9} \mathrm{H}_{2-}^{-}$ & 30.12 & 1.28 & $\mathrm{~m}$ & - \\
\hline$-\mathrm{C}^{10} \mathrm{H}_{2-}^{-}$ & 30.12 & 1.28 & $\mathrm{~m}$ & - \\
\hline$-\mathrm{C}^{11} \mathrm{H}_{2-}^{-}$ & 23.22 & 1.29 & $\mathrm{~m}$ & - \\
\hline$-\mathrm{C}^{12} \mathrm{H}_{3}$ & 14.35 & 0.88 & $\mathrm{t}$ & 7.00 \\
\hline
\end{tabular}

* Acylation site; $\mathrm{d}=$ doublet; $\mathrm{t}=$ triplet; $\mathrm{m}$ = multiplet.

To determine which primary carbon of the meso- and the pseudo-asymmetric polyol is bound to laurate, we measured a ${ }^{1} \mathrm{H}^{13} \mathrm{C}-\mathrm{HSQC}$ with high resolution in the direct dimension and no decoupling. Extraction of 1D slices along the respective carbon frequency allowed estimation of vicinal ${ }^{1 \mathrm{H}-1 \mathrm{H}} \mathrm{J}$ couplings. Figure $\mathrm{A} 1$ shows the signals that belong to $\mathrm{C}^{4} \mathrm{H}$ and $\mathrm{C}^{3} \mathrm{H}$ of the sorbitol. $\mathrm{C}^{4} \mathrm{H}$ is a triplet with coupling constants of $4.8 \mathrm{~Hz}$, indicating that both vicinal protons to this group are in cis position. $\mathrm{C}^{3} \mathrm{H}$, on the other hand, displayed a doublet of doublets with two different coupling constants of $5.3 \mathrm{~Hz}$ and $7.4 \mathrm{~Hz}$; thus, here, 
the vicinal protons are different, best explained by one in cis and the other in trans position. This proves that the laurate adduct is connected via the ester function to the $\mathrm{C}^{1} \mathrm{H}$ end of the polyol.

MS was performed with ElectroSpray Ionization (ESI) (Supplementary Materials, Figure S6). The spectrometric analysis of the synthesized SL is shown below in Table 4. In the latter, 5 clear adducts of SL have been observed and correlated to possible adducts.

Table 4. Adducts determined from the observed $\mathrm{m} / \mathrm{z}$ obtained via ElectroSpray IonizationQuadrupole (ESI-Q) experiment for the purified Sorbitol-6-O-Laurate (SL).

\begin{tabular}{ccc}
\hline Observed $m / z$ Value & Corresponding Adduct & Relative Abundance (\%) * \\
\hline 329.232 & {$\left[\mathrm{M}_{\mathrm{SL}}+\mathrm{H}\right]^{+}-2 \mathrm{H}_{2} \mathrm{O}$} & 7.27 \\
347.243 & {$\left[\mathrm{M}_{\mathrm{SL}}+\mathrm{H}\right]^{+}-\mathrm{H}_{2} \mathrm{O}$} & 100 \\
365.253 & {$\left[\mathrm{M}_{\mathrm{SL}}+\mathrm{H}^{+}\right.$} & 34.05 \\
382.280 & {$\left[\mathrm{M}_{\mathrm{SL}}+\mathrm{NH}_{4}\right]^{+}$} & 0.92 \\
387.235 & {$\left[\mathrm{M}_{\mathrm{SL}}+\mathrm{Na}^{+}\right.$} & 18.57 \\
\hline
\end{tabular}

* Calculated from the abundance of the ionic fragments on the y-axis, which was produced by in source fragmentation.

\subsection{Optimized Tube Scale Production and Scalabilty}

Combining the optimized factors allowed a product concentration of up to $50 \mathrm{~g} / \mathrm{L}$ of SL at the tube scale to be reached. Interestingly, to demonstrate the scalability of the production in a batch STR, we ended up with a $\sim 2$-fold decrease of both titer and yield, as shown in Table 5, suggesting that the reaction is sensitive to the effect of the reactor. Presumably, the chosen parameters such as stirring speed and stirring did not match the performance of orbital shaking and resulted in lower performance. Albeit we demonstrated in the present work the scalability of our process. More investigation specific on this reactor system that would focus on these parameters is needed.

Table 5. Impact of optimized factors on SL titer after $48 \mathrm{~h}$ in Sorbit DES with 5 wt.\% water, using Novozym $435^{\circledR}$ at tube and stirred-tank scales. Reaction conditions: $0.5 \mathrm{M}$ vinyl laurate, $50{ }^{\circ} \mathrm{C}$ and $50 \mathrm{~g} / \mathrm{L}$ enzyme formulation.

\begin{tabular}{|c|c|c|c|c|c|}
\hline \multirow{2}{*}{ Scale/Stirring } & \multirow{2}{*}{ Titer (g/L) } & \multirow{2}{*}{ Yield $* * *(\%)$} & \multicolumn{3}{|c|}{ Specific Reaction Velocity $* * *(\mu \mathrm{mol} / \mathrm{h} / \mathrm{g})$} \\
\hline & & & $4 \mathrm{~h}$ & $24 \mathrm{~h}$ & $48 \mathrm{~h}$ \\
\hline Tube/Orbital Shaking & $50 \pm 3 *$ & $28 \pm 2 *$ & $151 \pm 13^{*}$ & $91 \pm 4^{*}$ & $54 \pm 5$ * \\
\hline Stirred-Tank/3-bladed spiral propeller & $25 \pm 8^{* *}$ & $14 \pm 4^{* *}$ & $134 \pm 10^{* *}$ & $40 \pm 8^{* *}$ & $29 \pm 4^{* *}$ \\
\hline
\end{tabular}

${ }^{*} n=3, p$-value $<0.05 .{ }^{* *} n=2, p$-value $<0.1 .{ }^{* * *}$ Calculated from Equations (1) and (2), Section 4.9.

In Figure 5, we observe directly this blatant two-fold decrease in titer. However, it is interesting to notice an equivalent titer in the early stage of the reaction being reached in the STR and the orbitally shaken tubes with comparable initial velocities. After $24 \mathrm{~h}$, the difference in titer increases drastically while the specific productivity dropped in both reactors with a 1:2.5 ratio between the two systems. Finally, at $48 \mathrm{~h}$, reaction velocities decreased again by roughly 2 -fold, conserving a similar ratio as previous. Thus, it is suspected that, comparatively, the enzyme was inhibited due to mass transfer limitations in the STR.

We propose thereafter a discussion making a parallel between our results and preexisting ones in literature. Allowing us to give a broader aspect of the role of immobilized enzymes, DESs and reactor technologies in sustainable processes such as, but not only limited to, sugar ester synthesis. 


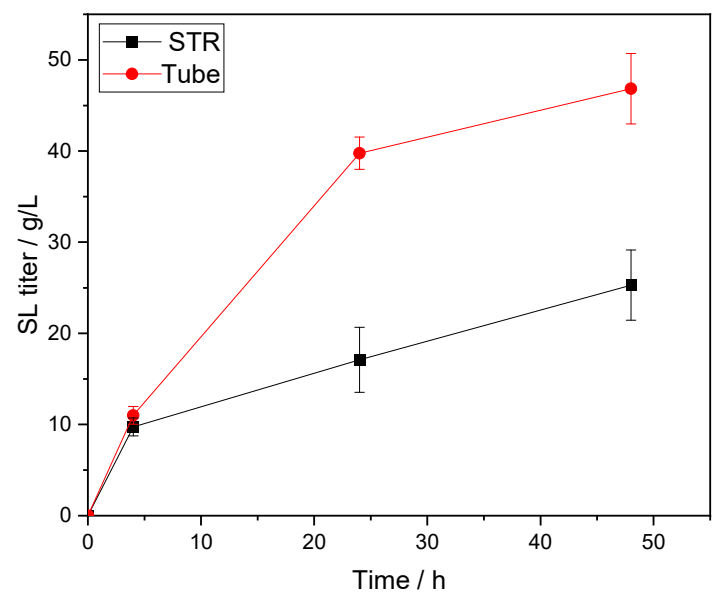

Figure 5. Time course of SL production ( $\mathrm{g} / \mathrm{L})$ : STR with 3-bladed spiral propeller versus tube in orbital shaking.

\section{Discussion}

\subsection{Immobilized Lipases and Media Tailoring for Sustainable Biocatalyzed Esterifications}

To enhance the performance of the biocatalyst, the immobilization of enzymes and, more specifically, lipases are of high industrial interest, and it has become a requirement [29]. Indeed, it was shown in numerous reports that through, e.g., adsorption or covalent binding with a solid carrier, some acyltransferases, such as the lipase B from Candida antarctica (CaLB), could display improved activity, stability and reusability [30-32]. This phenomenon can be understood inter alia as a gain of rigidity for the enzyme's tertiary structure, which limits protein unfolding and thus denaturation of the biocatalyst [33]. This is in practice true in the case of the Novozym $4355^{\circledR}$ formulation that was recently qualified as the "perfect immobilized biocatalyst" in a review from Ortiz et al. [34]. In parallel, the native CaLB has been demonstrated to be among the most stable commercially available lipases $[35,36]$. By binding it to a macroporous acrylic polymer resin (Lewatit VP OC 16,000), resulting in the now highly reported Novozym $435^{\circledR}$, it increased drastically the performances of the biocatalyst [37].

In the current work, it might appear shocking that we use $50 \mathrm{~g} / \mathrm{L}$ of the enzyme to reach the same value in titer of product. At least on the tube scale, it is likely that, in the case of Novozym $435^{\circledR}$, the costs associated with the immobilization might be fully compensated [38-48]. Indeed, the formulation can be recycled, using filtration, for sometimes up to 10 cycles, as a report from Liu et al. demonstrates [49]. It is also important to remember that in such a bead-adsorbed enzyme formulation, the non-catalytic ballast of the carrier represents a tremendous portion of the biocatalyst's mass (90 to $>99$ wt.\%) $[37,50]$. Thus, it is remarkable that in our work, the immobilized versions of CaLB, such as Lipozyme $435^{\circledR}$ or Novozym $435^{\circledR}$, rivalized with the buffered formulations as they should normally contain a higher enzyme concentration.

Interestingly, CLEA CA was, in our case, comparable to the other CaLB formulations. The Cross-Linked Enzyme Aggregates (CLEAs) first introduced by Sheldon et al. [51], but also the Cross-Linked Enzyme Crystals (CLECs) [52], represent very interesting and more elegant alternatives to the petrol-based polymer-carriers. CLEAs are a result of firsthand the precipitation and physical aggregation of the enzymes, then secondhand the cross-linking of these aggregates with a cross-linking agent, which can be typically glutaraldehyde. This gives several advantages to CLEAs over their non-covalently immobilized analogues, such as the quasi-nonexistent leaching of enzyme even under reportedly harsh conditions [53]. Due to the covalent inter-molecular binding, CLEAs and CLECs afford complete removal of the carriers, thus resulting in carrier-free immobilized enzymes. However, they also present limitations and challenges for their industrial-scale production, notably for the control of the enzyme's aggregation that can result in less active enzyme dimers [54]; thus, they 
are, to this day, rather rarely produced in bulk. On a side note, it is important to mention that standard acrylic-bead-immobilized enzymes were easier to handle throughout the tube-scale synthesis and downstream processing, than their CLEA analogues.

Herein, we reached an optimal titer after $48 \mathrm{~h}$ of reaction, which is like other reports dealing with enzymatic production of sugar esters in DESs [11] but much shorter than microbial fermentation to produce glycolipids. Indeed, as an example, to produce Mannosylerythritol Lipids (MELs), the average harvesting time is between 7 to 10 days for a titer ranging from $15 \mathrm{~g} / \mathrm{L}$ to $165 \mathrm{~g} / \mathrm{L}$, to obtain, in the case of the highest yields, complex mixtures of MELs [55-58]. Additionally, and as we demonstrated, fewer factors must be investigated when selectively producing tailor-made glycolipids using either free or immobilized enzymes. On the other hand, microorganisms, such as yeasts or fungi, exhibit much more complex behaviors that require acute control of the reaction conditions. In this specific case, and despite MELs being well established on the market, mixtures of products are often obtained, thus adding a degree of complexity to the DSP. Our process using a "2-in-1" DES as media is rather more straightforward comparatively, but more time and investigation are needed to overcome challenges to make it relevant for industrial production. In regard to DSP, it has been shown in several studies that DESs can be recycled as well [59-61]. In our case and for an efficient liquid-liquid extraction, the "2-in-1" DES was first disrupted via aqueous solvation. Thus, it could be foreseeable that choline chloride-rich wastes generated by such DES-mediated process could be re-valorized in feed additives [62] or as agrochemical active ingredients [63]. Unlike organic solvents, DESs do not have to undergo incineration; thus, their release in nature can be considered [64].

Analogously, a eutectic mixture using organic solvents (NaOH/DMSO/2M2B) was investigated by Kim et al. for the synthesis of SL using lauric acid, reaching exceptionally high yields (97\%) using $~ 500 \mathrm{~g} / \mathrm{L}$ of the enzyme [23]. Despite this remarkable achievement, we propose, in contrast, a method using a deep eutectic system made of ubiquitous, renewable and inexpensive compounds, such as choline chloride and sorbitol, using 10 times less biocatalyst. Concomitantly, they also reported an adverse effect of highly viscous mixtures on the reaction, which correlates to the decreased titer we obtained when the reaction's water content was set to $2.5 \mathrm{wt} . \%$. Overall, this might also explain our comparatively inferior conversion yields, as it seems that deep eutectic systems present challenges in terms of mass transfer limitations, meaning that our substrate hardly moves to the enzyme's active site. Zhao et al. reported a bisolvent system containing either ILs or DESs in combination with 2M2B for glucose-based fatty acid esters production. Similar factors were investigated and gave results equivalent to ours, such as an optimal enzyme content of $20 \mathrm{~g} / \mathrm{L}$ of Novozym $435^{\circledR}$ at $60{ }^{\circ} \mathrm{C}$ to reach $46 \%$ conversion yield from the $0.3 \mathrm{M}$ of vinyl ester used [65].

The ever-growing knowledge on enzyme immobilization and media-tailoring technologies have shown to be crucial tools to reach sustainability in biocatalysis. They are also of active interest for various industrial domains to develop greener and sustainable processes [18,66-69]. Regarding this aim and as performance is of keen interest for industrial application, reactor technology and scalability represent two important pillars as well.

\subsection{Reactor Technology: Toward Scaling-Up Lipase-Catalyzed Reactions}

The development of suitable reactors and technologies that support lipase-catalyzed reactions is a topical subject for both academia and industry. Some parameters inherent to reactors have been shown to be of high importance for the performance of the process. For example, the speed of stirring can drastically influence the initial velocity of the reaction and the conversion yield. This was clearly demonstrated in a research article from Korupp et al. dealing with the enzymatic production of glycerol adipate using Novozym $435^{\circledR}$ [70]. In the latter, they observed the highest conversion rates at $100 \mathrm{rpm}$. The type of stirrer did not significantly influence the reaction; however, it was observed that only a helicon ribbon stirrer gave uniform convection of both substrate and catalyst. A similar observation was made in our case using a 3-bladed spiral propeller instead 
of a 4-bladed flat turbine (unpublished data), suggesting that homogeneity of highly viscous mixtures can be reached optimally in an STR with stirrers that induce vertical convection due to a rather axial flow. Indeed, studies from Wiemann et al. and AnsorgeSchumacher et al. are suggesting that viscous mixtures requiring high energy input might have a deleterious effect on the physical and mechanical properties of immobilized formulations [71,72]. To corroborate these affirmations, a study from Keng et al. used a Rushton turbine impeller, providing this time a radial flow that was seemingly more adapted to the relatively lower viscosities of their $n$-hexane-based mixture [73]. In their report dealing with the Lipozyme RM IM-catalyzed palm esters synthesis, it was clearly concluded as well that the shear effect of high impeller speed on the enzyme particles caused an adverse effect on reaction performances. Thus, potentially explaining our significant loss of titer ( $\sim$-fold decrease) and lower reaction velocity when scaling up from the tube to the STR (Table 5 and Figure 5). Altogether, it seems that a compromise needs to be found on the stirrer type and its speed to conserve the integrity of the biocatalyst. In this regard, more stable lipase formulations are commercialized to respond to this problem. A good example is the recently co-developed and industrially produced CalB immo Plus ${ }^{\circledR}$ from c-Lecta and Purolite companies (www.c-lecta.com, Leipzig, Germany / www.purolite.com, King of Prussia, PA, USA). The highly hydrophobic carrier ECR1030M (DVB/acrylate copolymer) exhibits enhanced mechanical stability and offers a controlled size of spherical beads.

As a matter of fact, we mostly demonstrate what conditions were the most intrinsically influential on the reaction, but further studies would be needed to optimize the process at an even bigger scale. We essentially brought in the current work proof of the scalability of our process and, more generally, the scalability of the DES-mediated biocatalysis, which is scarcely represented in the literature [74]. Despite a lack of in-depth understanding of how mechanistically DESs can activate and stabilize lipases, the room for improvement of this topic toward industrial application is rather wide. However, we were able to demonstrate that the preparative scale is reachable using a facile and straightforward method that requires the minimum necessary equipment, as shown in the flowsheet of Figure 6. We removed, therein, the need for continuous $\mathrm{pH}$ and gas composition assessment that are standardly used in microbial fermentation, among other measurements that require probes combined with their respective computer software.
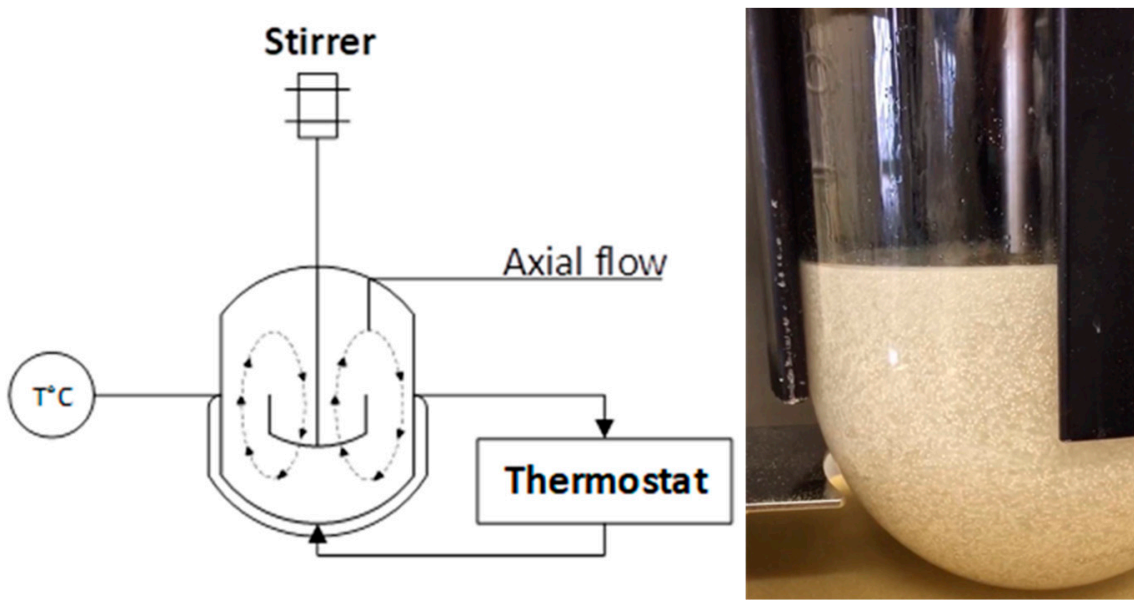

Figure 6. Flowsheet and picture illustrating the visibly homogenized lipase-catalyzed production of sugar alcohol monoesters using a stirred-tank reactor.

Although our discussion mainly revolved around the use of rather conventional reactors, such as STRs for batch heterogenous biocatalysis, innovative and commercially available alternatives have risen on the market. The Rotating Bed Reactors (RBRs), notably commercialized by the SpinChem company (www.spinchem.com, Tvistevägen, Sweden), 
have proven to be promising alternatives to STRs and have shown good results when used for immobilized enzymatic reactions [75]. Furthermore, their cooperation with Purolite (www.purolite.com, King of Prussia, PA, USA) gave light to immobilized lipase cartridges, theoretically forming a rotating packed bed reactor, which removes the need for filtration during the DSP and simplifies the recovery of the biocatalyst. Remarkably, packed bed reactors have also been combined with DESs for lipase-catalyzed esterifications. In a relatively recent study from Guajardo et al., they managed the transition from a batch to a fed-batch and continuous process, enhancing simultaneously conversion yield and productivity, thus seemingly resolving the encountered issue of mass transfer limitations and biocatalyst inhibition [76].

Recently as well, our research group published proof of a concept for the simultaneous extraction of lipids from yeast and the subsequent ester production in a "2-in-1" Sorbit DES, using microwave heating as an alternative to thermal heating [25]. This simplified and fast method is only an example of the vast possibilities that DESs, immobilized enzymes and innovative reactor systems can offer not only to the field of biocatalysis but also to biotechnology in a broader scope.

\section{Materials and Methods}

\subsection{Materials}

Vinyl laurate was purchased from Tokyo Chemical Industry Co., Ltd. (TCI Europe, Zwijndrecht, Belgium). Lipase formulations: Novozym $435^{\circledR}$, Lipozyme $435^{\circledR}$ and Novozym NS 81356 were given by Novozymes (Bagsværd, Denmark). CalB Immo Plus ${ }^{\circledR}$ was given by c-Lecta (Leipzig, Germany). CalA Immo 150, Lipase TL CLEA, Lipase CA CLEA and all other chemicals were purchased from either Carl Roth GbmH \& Co. KG (Karlsruhe, Germany) or Sigma Aldrich Chemie GmbH (Taufkirchen, Germany) if not stated otherwise. The other 9 lipase formulations were acquired in the Novozymes Lipase Screening Kit purchased from Strem Chemicals (Newburyport, MA, USA).

\subsection{DES Preparation and Standard SL Synthesis for Enzyme Formulation Screening}

The sorbitol and choline chloride-based DES, dubbed "Sorbit DES", was prepared and validated according to the procedure described by Dai et al. and Hayyan et al. [77,78]. The water content was varied $(1.25,2.5,5,7.5$ and $10 \mathrm{wt} . \%)$ then controlled according to the method described in Section 4.7.

In a $5 \mathrm{~mL}$ Eppendorf tube, were introduced subsequently $1.5 \mathrm{~mL}$ of warm Sorbit DES, vinyl laurate $(195 \mu \mathrm{L}, 170 \mathrm{mg}, 0.75 \mathrm{mmol}, 0.5 \mathrm{M})$ and $30 \mathrm{mg}$ of enzyme formulation $(20 \mathrm{~g} / \mathrm{L})($ Table 1$)$. The tubes containing the reaction mixture were agitated in a rotator and vortex mixer (program U2) from neoLab (Heidelberg, Germany) at $90 \mathrm{rpm}$ and $50{ }^{\circ} \mathrm{C}$. To get a triplicate for each measure, three tubes were collected for each time point at: 0.5, $4,8,24,28,32,48,72$ and $96 \mathrm{~h}$. The latter were then processed for further analysis as described in Section 4.8, the conversion yields were calculated as the percentage of molar ratio of sorbitol monoester produced to the total amount of vinyl laurate added to the reaction system.

\subsection{Enzyme Formulations Screening}

To compare the lipase formulations (Table 1), an identical concentration of the latter was used each time $(20 \mathrm{~g} / \mathrm{L})$, and the same substrate concentration ( $0.5 \mathrm{M}$ vinyl laurate) was provided to the media at $50^{\circ} \mathrm{C}$. For this comparison, the reaction was stopped after $48 \mathrm{~h}$.

\subsection{Influence of Enzyme Concentration}

In order to examine the optimal concentration of lipase formulation, different concentrations of Novozym $435^{\circledR}(10,20,30,40,50$ and $60 \mathrm{~g} / \mathrm{L})$ were tested without varying any other reaction parameter. 


\subsection{Optimization of Vinyl Laurate Amount}

To address the optimal vinyl fatty ester concentration for the reaction, different vinyl laurate concentrations $(0.25,0.5,0.75,1$ and $1.25 \mathrm{M})$ were tested. All other reaction conditions were kept constant.

\subsection{Water Content, Viscosity and Water Activity Analysis}

The water content was assessed with Karl-Fischer titration using a TritoLine $7500 \mathrm{KF}$ trace from SI Analytics (Mainz, Germany) at $20^{\circ} \mathrm{C}$ in combination with Aquastar CombiCoulomat fritless (Merck Millipore, Darmstadt, Germany) as analyte. Water standards of 0.1 and $1 \%$ in xylene from Merck Millipore (Darmstadt, Germany) were used to test the titrator's accuracy before the measurements.

The viscosity was measured at $50{ }^{\circ} \mathrm{C}$ with a viscosimeter MCR 501 using a CC10 concentric cylinder (Anton-Paar, Graz, Austria) with about $1 \mathrm{~mL}$ of liquid for each water content for the Sorbit DES.

The water activity was measured at $50{ }^{\circ} \mathrm{C}$ with a LabMaster-aw neo $\mathrm{A}_{\mathrm{w}}$ meter (Novasina, Lachen, Switzerland) using $3 \mathrm{~mL}$ of liquid for each water content for the Sorbit DES.

\subsection{Scale-Up Procedure and Downstream Processing for Standard and Bulk SL Production}

In a $2.5 \mathrm{~L}$ Minifors bioreactor (Infors HT, Bottmingen, Switzerland), $500 \mathrm{~mL}$ of warm Sorbit DES were introduced, prepared as described in Section 4.2. The medium temperature was first equilibrated to $50^{\circ} \mathrm{C}$ then subsequently were introduced $25 \mathrm{~g}$ of Novozym $435^{\circledR}$ $(50 \mathrm{~g} / \mathrm{L})$ and vinyl laurate $(65 \mathrm{~mL}, 56.62 \mathrm{~g}, 0.25 \mathrm{~mol}, 0.5 \mathrm{M})$. The reaction mixture was stirred at $300 \mathrm{rpm}$ with a single three-bladed spiral propeller $(\mathrm{D}=54 \times 12 \mathrm{~mm})$ (Infors HT, Bottmingen, Switzerland). After $48 \mathrm{~h}$, the reaction was stopped, the media diluted with $500 \mathrm{~mL}$ of double-distilled water and filtrated through a Büchner funnel. In total, $200 \mathrm{~mL}$ of brine were incorporated into the aqueous phase that was then extracted 6 times with a 1:1 volume ratio of ethyl acetate. The organic phases were gathered and chemically dried over $\mathrm{MgSO}_{4}$ before being dry evaporated with a rotative evaporator.

For the purification of the SL standard that was used for the calibration curve, $2 \mathrm{~g}$ of the crude paste was re-dissolved in chloroform to be adsorbed over $4 \mathrm{~g}$ of Celite 545 for flash chromatography purification using the solid loading method. To purify this crude, a Reveleris PREP purification system equipped with a $12 \mathrm{~g}$ Chromabond ${ }^{\circledR}$ Flash RS 15 Sphere SiOH column (Macherey-Nagel, Düren, Germany) was used. Elution solvents were chloroform and methanol with a gradient such as 2 nd solvent percentage started at $0 \%$ for $1.5 \mathrm{~min}, 7 \%$ for $9.5 \mathrm{~min}, 15 \%$ for $3 \mathrm{~min}$ and finally $100 \%$ for $3 \mathrm{~min}$. The second fraction, containing SL, was collected at $7.5 \mathrm{~min}$. The latter was dry evaporated on a rotary evaporator for further use and analysis; $\sim 0.75 \mathrm{~g}$ of dried, white powder (Supplementary Materials, Figure S7).

For bulk production of SL, the entire crude ( $25 \mathrm{~g})$ was re-dissolved in the necessary minimal volume of ethyl acetate $(\sim 400 \mathrm{~mL})$ and washed with $1 \times 400 \mathrm{~mL}$ of brine, and then $3 \times 400 \mathrm{~mL}$ of double-distilled water to remove unreacted sorbitol. The organic phase was dried over $\mathrm{MgSO}_{4}$ and dry evaporated on a rotary evaporator; $\sim 10 \mathrm{~g}$ of dried, white powder (Supplementary Materials, Figure S8).

\subsection{Sample Preparation and HPLC-ELSD Quantification Method}

Tubes produced by the methods described in Sections 4.2-4.5 were prepared and analyzed as follows. For extraction of the glycolipid and its quantification with HPLCELSD, the following procedure was applied. First, $1 \mathrm{~mL}$ of double-distilled water was added to the tube containing the reaction mixture and vortexed for $45 \mathrm{~s}$. Then, $2.5 \mathrm{~mL}$ of ethyl acetate was added to the warm solubilized DES; subsequently, the extraction took place at $50{ }^{\circ} \mathrm{C}$ for $20 \mathrm{~min}$ with the use of the orbital shaker set on program U2 and $90 \mathrm{rpm}$ (neoLab, Heidelberg, Germany). Then, $1 \mathrm{~mL}$ of the upper phase was aliquoted and dried on a centrifugal evaporator in order to be resolubilized in $1 \mathrm{~mL}$ of chloroform/methanol (75:25 $v / v)$, and $100 \mu \mathrm{L}$ was placed into an HPLC vial for further quantification. 
The method described by Hollenbach et al. [28,79] was used with slight modifications as follows. Kinetex EVO C18 $(2.6 \mathrm{~mm}, 250 \mathrm{~mm} \times 4.6 \mathrm{~mm})$ column from Phenomenex (Aschaffenburg, Germany) with an accompanying guard column ( $4 \mathrm{~mm} \times 3.0 \mathrm{~mm}$ ID) of the same phase, using an Agilent 1260 series liquid chromatograph (Waldbronn, Germany) equipped with a quaternary pump, an autosampler and a column oven. An evaporative light scattering detector (ELSD) from BÜCHI Labortechnik (Essen, Germany) was used for detection. The mobile phase, solvent A, was water and solvent B was acetonitrile. The flow rate was $1 \mathrm{~mL} / \mathrm{min}$, and a gradient was used for separation of product and substrates: starting from $40 \% \mathrm{~A}-60 \% \mathrm{~B}$, then $0-10 \mathrm{~min}$ a linear gradient up to $35 \% \mathrm{~A}-65 \% \mathrm{~B}$, followed by another linear gradient from 10 to 15 min up to $25 \%$ A-75\% B. This gradient was held for $5 \mathrm{~min}$, followed by a reconditioning step of the column with $40 \%$ A-60\% B for $5 \mathrm{~min}$. The injection volume was set to $10 \mu \mathrm{L}$. The column was operated at $50{ }^{\circ} \mathrm{C}$. The detector was operated at $38^{\circ} \mathrm{C}$ with a gas flow (air) of $1.5 \mathrm{~mL} / \mathrm{min}$. The gain was set to 1 . The retention times were $2.1 \mathrm{~min}$ for sorbitol, $3.5 \mathrm{~min}$ for SL and $~ 9.5 \mathrm{~min}$ for lauric acid (Supplementary Materials, Figure S1).

$$
\begin{gathered}
\text { Yield }[\%]=\frac{\mathrm{nSL}[\mathrm{mol}]}{\mathrm{nVinyl} \text { laurate }[\mathrm{mol}]} \times 100 \% \\
\text { Specific reaction velocity }[\mu \mathrm{mol} / \mathrm{h} / \mathrm{g}]=\frac{\mathrm{nSL}[\mu \mathrm{mol}]}{\mathrm{mBiocatalyst}[\mathrm{g}] \times \text { time }[\mathrm{h}]}
\end{gathered}
$$

n: number of moles.

m: mass.

\subsection{Spectroscopic and Spectrometric Methods for Structural Elucidation of SL}

For nuclear magnetic resonance (NMR) spectroscopy, $10 \mathrm{mg}$ of purified SL was dissolved in $0.6 \mathrm{~mL} \mathrm{CD} \mathrm{Cl}_{2} / d_{6}$-acetone (4:1, by vol.). Then, $1 \mathrm{D}{ }^{1} \mathrm{H}-\mathrm{NMR}$ spectroscopy and $2 \mathrm{D}{ }^{1} \mathrm{H}-{ }^{1} \mathrm{H}$ correlation spectroscopy (COSY), ${ }^{1} \mathrm{H}-{ }^{1} \mathrm{H}$ total correlation spectroscopy (TOCSY), ${ }^{1} \mathrm{H}^{13} \mathrm{C}$ heteronuclear single-quantum correlation (HSQC) spectroscopy and ${ }^{1} \mathrm{H}-{ }^{13} \mathrm{C}$-heteronuclear multiple-bond correlation (HMBC) spectroscopy were performed on a Bruker AVANCE III $600 \mathrm{MHz}$ spectrometer (Bruker BioSpin, Rheinstetten, Germany) equipped with a TCI cryoprobe at a temperature of $27^{\circ} \mathrm{C}$. Spectra were processed and analyzed using Topspin 4.0.1 (Bruker BioSpin) and MestReNova 14.2.0 (Mestrelab Research S.L., Santiago de Compostela, Spain). Chemical shifts were referenced to the ${ }^{1} \mathrm{H}$ and ${ }^{13} \mathrm{C}$-resonance of tetramethylsilane (TMS).

The mass spectrometry (MS) for mass identifications was performed with electrospray ionization (ESI) on a quadrupole Q Exactive Plus (ThermoFisher Scientific GmbH, Kandel, Germany) and recorded in positive mode, and raw spectrometric data were treated using MestReNova Suite 2020 (version 14.2.0) (Mestrelab Research S.L., Santiago de Compostela, Spain).

\subsection{Data Treatment and Statistical Analysis}

OriginPro software 9.7 (version 2020) (OriginLab Corporation, Northampton, MA, USA) was used for raw data treatment and statistical analysis. Results are presented as mean \pm standard deviation $(n=3)$. Statistical analysis was performed by one-way ANOVA and Tukey test, and the results were considered significant if the $p$-value was $<0.05$ if not stated otherwise.

\section{Conclusions}

In this work, we presented the screening of 16 commercially available lipase formulations for the DES-mediated and lipase-catalyzed production of glycolipid sorbitol-6-Olaurate. We determined the influence of several factors, such as time of reaction, enzyme dosage, substrate concentration and water content, when using Novozym $435^{\circledR}$ as biocatalyst owing to our newly HPLC-ELSD quantification method. We, therein, elucidated 
and identified, with complete spectroscopy and spectrometry analysis, the structure of the targeted compound. To finalize our report, we brought evidence of the possible scalability of the process and its importance for sustainable biocatalysis by highlighting analogous knowledge and facts from the literature. Overall, we show that despite many challenges and limitations, DESs demonstrate factually potential for mediating bioprocesses. Thus, it is foreseeable that more and more concrete applications will emerge concerning this specific topic.

Supplementary Materials: The following are available online, Figure S1: Chromatogram of HPLCELSD separation of extracts from glycolipid synthesis. At $2.1 \mathrm{~min}$ elutes the sorbitol, at $3.6 \mathrm{~min}$ the sorbitol-6-O-laurate and around $9.5 \mathrm{~min}$ the lauric acid (not integrated); Figure S2: 2D-NMR experiment: ${ }^{1} \mathrm{H}-{ }^{1} \mathrm{H}$ COSY of SL; Figure S3: 2D-NMR experiment: ${ }^{1} \mathrm{H}_{-}{ }^{1} \mathrm{H}$ TOCSY of SL; Figure S4: 2D-NMR experiment: ${ }^{1} \mathrm{H}_{-}{ }^{13} \mathrm{C}$ HSQC of SL; Figure S5: 2D-NMR experiment: ${ }^{1} \mathrm{H}_{-}{ }^{13} \mathrm{C}$ HMBC of SL; Figure S6: Mass spectroscopy using ESI-Q measurements: spectra of the purified sorbitol-6O-laurate; Figure S7: (A) Chromatogram of the flash-chromatography purification of sorbitol-6-Olaurate. (B) Chromatogram for the purity assessment of the resulting sorbitol-6-O-laurate standard; Figure S8: Chromatogram for the purity assessment of the resulting sorbitol-6-O-laurate from the STR production using liquid-liquid extraction for DSP.

Author Contributions: Conceptualization, A.D.; methodology, A.D., O.O., H.S., C.M.-G. and K.O.; formal analysis, A.D., O.O., L.L., H.S. and C.M.-G.; investigation, A.D., O.O., L.L., H.S. and C.M.-G.; writing—original draft preparation, A.D.; writing—review and editing, A.D., O.O., H.S., C.M.-G. and K.O.; supervision, C.S. and K.O.; funding acquisition, C.S. All authors have read and agreed to the published version of the manuscript.

Funding: This work by A.D. was supported by the Bundesministerium für Bildung und Forschung (BMBF Allianz Biotenside AZ: 031B0469C). H.S. acknowledges support by the Deutsche Forschungsgemeinschaft (DFG, German Research Foundation) under Germany's Excellence Strategy via the Excellence Cluster 3D Matter Made to Order (EXC-2082/1-390761711). C.M.G. acknowledges funding by the Helmholtz-Society. We gratefully thank the Open Access Publishing Fund of the Karlsruhe Institute of Technology.

Institutional Review Board Statement: Not applicable.

Informed Consent Statement: Not applicable.

Data Availability Statement: The main data presented in this study are available in the Supplementary Materials.

Acknowledgments: The authors gratefully acknowledge Novozymes (Denmark) for the gift of enzyme formulations that helped this work and especially Ramiro Martinez Gutierrez. We thank Andreas Vogel from c-Lecta (Germany) for the gift of CalB Immo Plus ${ }^{\circledR}$. Additionally, we thank Bernd Seidendorf from Macherey-Nagel (Germany) for his advice concerning chromatography purification. We also express deep thanks to Karolin Kohnle, Qais Ahmad Parsa, Simon Oswald, Jasmin Busch, Lara Hirsch, Despina Savvidou and the team of Stefan Bräse from the Institute of Organic Chemistry of the KIT (Karlsruhe, Germany) for performing the MS analysis.

Conflicts of Interest: The authors declare no conflict of interest.

Sample Availability: Samples of sorbitol-6-O-laurate are available from the authors.

\section{Appendix A}

Table A1. Averaged values of viscosity and water activity of the Sorbit DES under various water contents at $50{ }^{\circ} \mathrm{C}$.

\begin{tabular}{cccccc}
\hline Water content (wt. \%) & 1.25 & 2.5 & 5 & 7.5 & 10 \\
Viscosity $\left(\mathrm{Pa} \mathrm{s}^{-1}\right)$ & 1.55 & 1.07 & 0.56 & 0.35 & 0.27 \\
Water activity $\left(\mathrm{A}_{\mathrm{w}}\right)$ & 0.024 & 0.045 & 0.077 & 0.12 & 0.16 \\
\hline
\end{tabular}




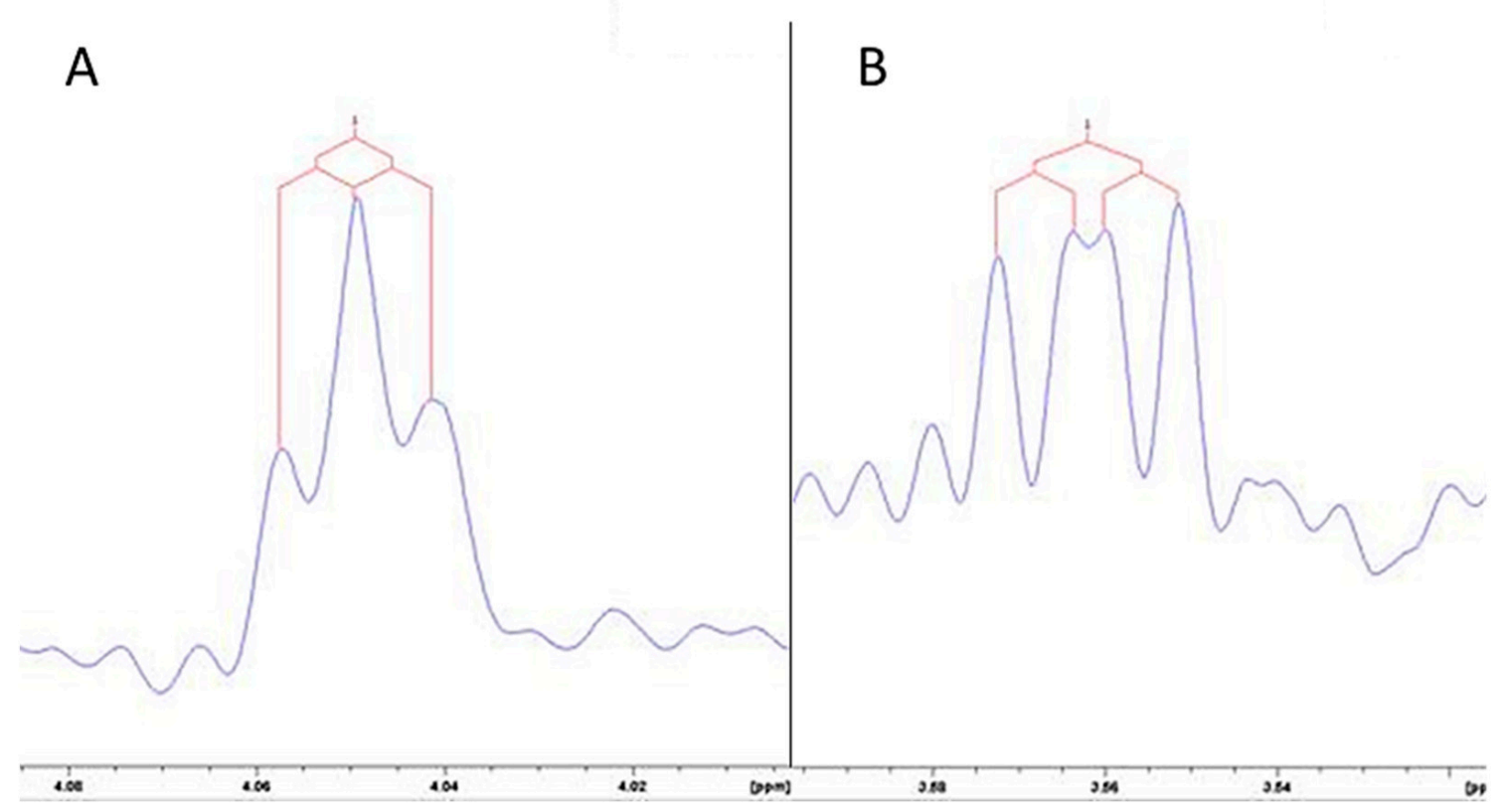

Figure A1. Extracted NMR signals of (A) $\mathrm{C}^{4} \mathrm{H}$ and (B) $\mathrm{C}^{3} \mathrm{H}$ of the sorbitol.

\section{References}

1. Paulino, B.N.; Pessôa, M.G.; Mano, M.C.R.; Molina, G.; Neri-Numa, I.A.; Pastore, G.M. Current status in biotechnological production and applications of glycolipid biosurfactants. Appl. Microbiol. Biotechnol. 2016, 100, 10265-10293. [CrossRef] [PubMed]

2. Inès, M.; Dhouha, G. Glycolipid biosurfactants: Potential related biomedical and biotechnological applications. Carbohydr. Res. 2015, 416, 59-69. [CrossRef] [PubMed]

3. Dhasayan, A.; Kiran, G.S.; Selvin, J. Production and Characterisation of Glycolipid Biosurfactant by Halomonas sp. MB-30 for Potential Application in Enhanced oil Recovery. Appl. Biochem. Biotechnol. 2014, 174, 2571-2584. [CrossRef] [PubMed]

4. Selmair, P.L.; Koehler, P. Role of glycolipids in breadmaking. Lipid Technol. 2010, 22, 7-10. [CrossRef]

5. Banat, I.M.; Carboué, Q.; Saucedo-Castañeda, G.; Cázares-Marinero, J.D.J. Biosurfactants: The green generation of speciality chemicals and potential production using Solid-State fermentation (SSF) technology. Bioresour. Technol. 2021, $320,124222$. [CrossRef] [PubMed]

6. Anastas, P.T. Benign by Design Chemistry. In Benign by Design; Anastas, P.T., Farris, C.A., Eds.; American Chemical Society: Washington, DC, USA, 1994; Volume 577, pp. 2-22. ISBN 978-0-8412-3053-8. [CrossRef]

7. Anastas, P.; Warner, J. Green Chemistry: Theory and Practice; Oxford University Press: Oxford, UK; New York, NY, USA, 2000; ISBN 978-0-19-850698-0.

8. Grüninger, J.; Delavault, A.; Ochsenreither, K. Enzymatic glycolipid surfactant synthesis from renewables. Process. Biochem. 2019, 87, 45-54. [CrossRef]

9. Lipshutz, B.H.; Ghorai, S. Transitioning organic synthesis from organic solvents to water. What's your E Factor? Green Chem. 2014, 16, 3660-3679. [CrossRef]

10. Shin, D.W.; Mai, N.L.; Bae, S.-W.; Koo, Y.-M. Enhanced lipase-catalyzed synthesis of sugar fatty acid esters using supersaturated sugar solution in ionic liquids. Enzym. Microb. Technol. 2019, 126, 18-23. [CrossRef]

11. Pöhnlein, M.; Ulrich, J.; Kirschhöfer, F.; Nusser, M.; Muhle-Goll, C.; Kannengiesser, B.; Brenner-Weiß, G.; Luy, B.; Liese, A.; Syldatk, C.; et al. Lipase-catalyzed synthesis of glucose-6-O-hexanoate in deep eutectic solvents. Eur. J. Lipid Sci. Technol. 2015, 117, 161-166. [CrossRef]

12. Abbott, A.P.; Capper, G.; Davies, D.L.; Rasheed, R.K.; Tambyrajah, V. Novel solvent properties of choline chloride/urea mixtures. Chem. Commun. 2003, 70-71. [CrossRef] [PubMed]

13. Durand, E.; LeComte, J.; Villeneuve, P. From green chemistry to nature: The versatile role of low transition temperature mixtures. Biochim. 2016, 120, 119-123. [CrossRef]

14. Di Gioia, M.L.; Nardi, M.; Costanzo, P.; De Nino, A.; Maiuolo, L.; Oliverio, M.; Procopio, A. Biorenewable Deep Eutectic Solvent for Selective and Scalable Conversion of Furfural into Cyclopentenone Derivatives. Molecules 2018, 23, 1891. [CrossRef] [PubMed]

15. Piemontese, L.; Sergio, R.; Rinaldo, F.; Brunetti, L.; Perna, F.M.; Santos, M.A.; Capriati, V. Deep Eutectic Solvents as Effective Reaction Media for the Synthesis of 2-Hydroxyphenylbenzimidazole-Based Scaffolds en Route to Donepezil-Like Compounds. Molecules 2020, 25, 574. [CrossRef]

16. Di Gioia, M.L.; Cassano, R.; Costanzo, P.; Cano, N.H.; Maiuolo, L.; Nardi, M.; Nicoletta, F.P.; Oliverio, M.; Procopio, A. Green Synthesis of Privileged Benzimidazole Scaffolds Using Active Deep Eutectic Solvent. Molecules 2019, 24, 2885. [CrossRef] [PubMed] 
17. Bonacci, S.; Di Gioia, M.L.; Costanzo, P.; Maiuolo, L.; Tallarico, S.; Nardi, M. Natural Deep Eutectic Solvent as Extraction Media for the Main Phenolic Compounds from Olive Oil Processing Wastes. Antioxidants 2020, 9, 513. [CrossRef]

18. Pätzold, M.; Siebenhaller, S.; Kara, S.; Liese, A.; Syldatk, C.; Holtmann, D. Deep Eutectic Solvents as Efficient Solvents in Biocatalysis. Trends Biotechnol. 2019, 37, 943-959. [CrossRef] [PubMed]

19. Siebenhaller, S.; Muhle-Goll, C.; Luy, B.; Kirschhöfer, F.; Brenner-Weiss, G.; Hiller, E.; Günther, M.; Rupp, S.; Zibek, S.; Syldatk, C. Sustainable enzymatic synthesis of glycolipids in a deep eutectic solvent system. J. Mol. Catal. B Enzym. 2016, 133, S281-S287. [CrossRef]

20. Bornscheuer, U.T.; Yamane, T. Fatty acid vinyl esters as acylating agents: A new method for the enzymatic synthesis of monoacylglycerols. J. Am. Oil Chem. Soc. 1995, 72, 193-197. [CrossRef]

21. Jeon, G.-J.; Park, O.-J.; Hur, B.-K.; Yang, J.-W. Enzymatic synthesis of amino acid-sugar alcohol conjugates in organic media. Biotechnol. Lett. 2001, 23, 929-934. [CrossRef]

22. Jahangiri, A.; Møller, A.H.; Danielsen, M.; Madsen, B.; Joernsgaard, B.; Vaerbak, S.; Adlercreutz, P.; Dalsgaard, T.K. Hydrophilization of bixin by lipase-catalyzed transesterification with sorbitol. Food Chem. 2018, 268, 203-209. [CrossRef]

23. Kim, H.J.; Youn, S.H.; Shin, C.S. Lipase-catalyzed synthesis of sorbitol-fatty acid esters at extremely high substrate concentrations. J. Biotechnol. 2006, 123, 174-184. [CrossRef]

24. Seino, H.; Uchibori, T.; Nishitani, T.; Inamasu, S. Enzymatic synthesis of carbohydrate esters of fatty acid (I) esterification of sucrose, glucose, fructose and sorbitol. J. Am. Oil Chem. Soc. 1984, 61, 1761-1765. [CrossRef]

25. Delavault, A.; Ochs, K.; Gorte, O.; Syldatk, C.; Durand, E.; Ochsenreither, K. Microwave-Assisted One-Pot Lipid Extraction and Glycolipid Production from Oleaginous Yeast Saitozyma podzolica in Sugar Alcohol-Based Media. Molecules 2021, 26, 470. [CrossRef] [PubMed]

26. Elmowafy, E.; El-Derany, M.O.; Biondo, F.; Tiboni, M.; Casettari, L.; Soliman, M.E. Quercetin Loaded Monolaurate Sugar Esters-Based Niosomes: Sustained Release and Mutual Antioxidant-Hepatoprotective Interplay. Pharmaceutics 2020, $12,143$. [CrossRef]

27. Siebenhaller, S.; Kirchhoff, J.; Kirschhöfer, F.; Brenner-Weiß, G.; Muhle-Goll, C.; Luy, B.; Haitz, F.; Hahn, T.; Zibek, S.; Syldatk, C.; et al. Integrated Process for the Enzymatic Production of Fatty Acid Sugar Esters Completely Based on Lignocellulosic Substrates. Front. Chem. 2018, 6, 421. [CrossRef]

28. Hollenbach, R.; Ochsenreither, K.; Syldatk, C. Enzymatic Synthesis of Glucose Monodecanoate in a Hydrophobic Deep Eutectic Solvent. Int. J. Mol. Sci. 2020, 21, 4342. [CrossRef]

29. Chandra, P.; Enespa; Singh, R.; Arora, P.K. Microbial lipases and their industrial applications: A comprehensive review. Microb. Cell Factories 2020, 19, 1-42. [CrossRef]

30. Adlercreutz, P. Immobilisation and application of lipases in organic media. Chem. Soc. Rev. 2013, 42, 6406-6436. [CrossRef]

31. Arroyo, M.; Sánchez-Montero, J.M.; Sinisterra, J.V. Thermal stabilization of immobilized lipase B from Candida antarctica on different supports: Effect of water activity on enzymatic activity in organic media. Enzym. Microb. Technol. 1999, $24,3-12$. [CrossRef]

32. Krasňan, V.; Stloukal, R.; Rosenberg, M.; Rebroš, M. Immobilization of cells and enzymes to LentiKats®. Appl. Microbiol. Biotechnol. 2016, 100, 2535-2553. [CrossRef]

33. Wahab, R.A.; Elias, N.; Abdullah, F.; Ghoshal, S.K. On the taught new tricks of enzymes immobilization: An all-inclusive overview. React. Funct. Polym. 2020, 152, 104613. [CrossRef]

34. Ortiz, C.; Ferreira, M.L.; Barbosa, O.; Dos Santos, J.C.S.; Rodrigues, R.C.; Berenguer-Murcia, Á.; Briand, L.E.; Fernandez-Lafuente, R. Novozym 435: The "perfect" lipase immobilized biocatalyst? Catal. Sci. Technol. 2019, 9, 2380-2420. [CrossRef]

35. Arana-Peña, S.; Lokha, Y.; Fernández-Lafuente, R. Immobilization of Eversa Lipase on Octyl Agarose Beads and Preliminary Characterization of Stability and Activity Features. Catalysts 2018, 8, 511. [CrossRef]

36. Arana-Peña, S.; Lokha, Y.; Fernández-Lafuente, R. Immobilization on octyl-agarose beads and some catalytic features of commercial preparations of lipase a from Candida antarctica (Novocor ADL): Comparison with immobilized lipase B from Candida antarctica. Biotechnol. Prog. 2019, 35, e2735. [CrossRef]

37. De Souza, S.P.; De Almeida, R.A.; Garcia, G.G.; Leão, R.A.; Bassut, J.; De Souza, R.O.; Itabaiana, I. Immobilization of lipase B fromCandida antarcticaon epoxy-functionalized silica: Characterization and improving biocatalytic parameters. J. Chem. Technol. Biotechnol. 2018, 93, 105-111. [CrossRef]

38. Mateo, C.; Palomo, J.M.; Fernandez-Lorente, G.; Guisan, J.M.; Fernandez-Lafuente, R. Improvement of enzyme activity, stability and selectivity via immobilization techniques. Enzym. Microb. Technol. 2007, 40, 1451-1463. [CrossRef]

39. Sheldon, R.A. Enzyme Immobilization: The Quest for Optimum Performance. Adv. Synth. Catal. 2007, 349, 1289-1307. [CrossRef]

40. Barbosa, O.; Ortiz, C.; Berenguer-Murcia, Á.; Torres, R.; Rodrigues, R.C.; Fernandez-Lafuente, R. Strategies for the one-step immobilization-purification of enzymes as industrial biocatalysts. Biotechnol. Adv. 2015, 33, 435-456. [CrossRef]

41. Rodrigues, R.C.; Ortiz, C.; Berenguer-Murcia, Á.; Torres, R.; Fernández-Lafuente, R. Modifying enzyme activity and selectivity by immobilization. Chem. Soc. Rev. 2013, 42, 6290-6307. [CrossRef]

42. Garcia-Galan, C.; Berenguer-Murcia, Á.; Fernandez-Lafuente, R.; Rodrigues, R.C. Potential of Different Enzyme Immobilization Strategies to Improve Enzyme Performance. Adv. Synth. Catal. 2011, 353, 2885-2904. [CrossRef]

43. Brady, D.; Jordaan, J. Advances in enzyme immobilisation. Biotechnol. Lett. 2009, 31, 1639-1650. [CrossRef] [PubMed]

44. Tran, D.N.; Balkus, J.K.J. Perspective of Recent Progress in Immobilization of Enzymes. ACS Catal. 2011, 1, 956-968. [CrossRef] 
45. Mohamad, N.R.; Marzuki, N.H.C.; Buang, N.A.; Huyop, F.; Wahab, R.A. An overview of technologies for immobilization of enzymes and surface analysis techniques for immobilized enzymes. Biotechnol. Biotechnol. Equip. 2015, 29, 205-220. [CrossRef]

46. Guzik, U.; Hupert-Kocurek, K.; Wojcieszyńska, D. Immobilization as a Strategy for Improving Enzyme Properties-Application to Oxidoreductases. Molecules 2014, 19, 8995-9018. [CrossRef]

47. Homaei, A.A.; Sariri, R.; Vianello, F.; Stevanato, R. Enzyme immobilization: An update. J. Chem. Biol. 2013, 6, 185-205. [CrossRef]

48. Singh, R.K.; Tiwari, M.K.; Singh, R.; Lee, J.-K. From Protein Engineering to Immobilization: Promising Strategies for the Upgrade of Industrial Enzymes. Int. J. Mol. Sci. 2013, 14, 1232-1277. [CrossRef]

49. Liu, W.; Duan, F. Lipase-catalyzed transesterification of epoxidized soybean oil to prepare epoxy methyl esters. Grasas y Aceites 2018, 69, 247. [CrossRef]

50. Sheldon, R.A. Cross-linked Enzyme Aggregates (CLEAs): From Concept to Industrial Biocatalyst. In Biocatalysis: An Industrial Perspective; Catalysis Series; Royal Society of Chemistry: London, UK, 2017; Chapter 14; pp. 363-396. [CrossRef]

51. Sheldon, R.A.; Schoevaart, R.; Van Langen, L.M. Cross-linked enzyme aggregates (CLEAs): A novel and versatile method for enzyme immobilization (a review). Biocatal. Biotransformation 2005, 23, 141-147. [CrossRef]

52. Roy, J.J.; Abraham, T.E. Strategies in Making Cross-Linked Enzyme Crystals. Chem. Rev. 2004, 104, 3705-3722. [CrossRef]

53. Sheldon, R.A.; Sorgedrager, M.; Janssen, M.H. Use of Cross-Linked Enzyme Aggregates (CLEAs) for Performing Biotransformations. Chim. Oggi 2007, 25, 62.

54. Palomo, J.M.; Fuentes, M.; Fernández-Lorente, G.; Mateo, C.; Guisan, J.M.; Fernández-Lafuente, R. General Trend of Lipase to Self-Assemble Giving Bimolecular Aggregates Greatly Modifies the Enzyme Functionality. Biomacromolecules 2003, 4, 1-6. [CrossRef] [PubMed]

55. Arutchelvi, J.I.; Bhaduri, S.; Uppara, P.V.; Doble, M. Mannosylerythritol lipids: A review. J. Ind. Microbiol. Biotechnol. 2008, 35, 1559-1570. [CrossRef] [PubMed]

56. Saika, A.; Koike, H.; Fukuoka, T.; Morita, T. Tailor-made mannosylerythritol lipids: Current state and perspectives. Appl. Microbiol. Biotechnol. 2018, 102, 6877-6884. [CrossRef] [PubMed]

57. Ceresa, C.; Hutton, S.; Lajarin-Cuesta, M.; Heaton, R.; Hargreaves, I.; Fracchia, L.; De Rienzo, M.A.D. Production of Mannosylerythritol Lipids (MELs) to be Used as Antimicrobial Agents Against S. aureus ATCC 6538. Curr. Microbiol. 2020, 77, 1373-1380. [CrossRef]

58. Niu, Y.; Wu, J.; Wang, W.; Chen, Q. Production and characterization of a new glycolipid, mannosylerythritol lipid, from waste cooking oil biotransformation by Pseudozyma aphidis ZJUDM34. Food Sci. Nutr. 2019, 7, 937-948. [CrossRef] [PubMed]

59. Cui, Y.; Li, C.; Bao, M. Deep eutectic solvents (DESs) as powerful and recyclable catalysts and solvents for the synthesis of 3,4-dihydropyrimidin-2(1H)-ones/thiones. Green Process. Synth. 2019, 8, 568-576. [CrossRef]

60. Liang, X.; Fu, Y.; Chang, J. Effective separation, recovery and recycling of deep eutectic solvent after biomass fractionation with membrane-based methodology. Sep. Purif. Technol. 2019, 210, 409-416. [CrossRef]

61. Jeong, K.M.; Lee, M.S.; Nam, M.W.; Zhao, J.; Jin, Y.; Lee, D.-K.; Kwon, S.W.; Jeong, J.H.; Lee, J. Tailoring and recycling of deep eutectic solvents as sustainable and efficient extraction media. J. Chromatogr. A 2015, 1424, 10-17. [CrossRef]

62. Fouladi, P.; Salamat, R.; Ahmadzadehe, A.; Shahryar, H.A.; Noshadi, N. Effect of Choline Chloride Supplement on the Internal Organs and Carcass Weight of Broilers Chickens. J. Anim. Vet. Adv. 2008, 7, 1164-1167.

63. Sclapari, T.; Bramati, V.; Erba, A. New Uses of Choline Chloride in Agrochemical Formulations. US Patent US20140194289A1, 3 October 2012.

64. Seyler, C.; Capello, C.; Hellweg, S.; Bruder, C.; Bayne, D.; Huwiler, A.; Hungerbühler, K. Waste-Solvent Management as an Element of Green Chemistry: A Comprehensive Study on the Swiss Chemical Industry. Ind. Eng. Chem. Res. 2006, 45, 7700-7709. [CrossRef]

65. Zhao, K.-H.; Cai, Y.-Z.; Lin, X.-S.; Xiong, J.; Halling, P.J.; Yang, Z. Enzymatic Synthesis of Glucose-Based Fatty Acid Esters in Bisolvent Systems Containing Ionic Liquids or Deep Eutectic Solvents. Molecules 2016, 21, 1294. [CrossRef]

66. Abbott, B.J. Preparation of Pharmaceutical Compounds by Immobilized Enzymes and Cells. In Advances in Applied Microbiology; Perlman, D., Ed.; Academic Press: Cambridge, MA, USA, 1976; Volume 20, pp. 203-257. [CrossRef]

67. Ansörge-Schumacher, M.B.; Thum, O. Immobilised lipases in the cosmetics industry. Chem. Soc. Rev. 2013, 42, 6475. [CrossRef]

68. Basso, A.; Serban, S. Industrial applications of immobilized enzymes-A review. Mol. Catal. 2019, 479, 110607. [CrossRef]

69. Hassan, M.E.; Yang, Q.; Xiao, Z.; Liu, L.; Wang, N.; Cui, X.; Yang, L. Impact of immobilization technology in industrial and pharmaceutical applications. 3 Biotech 2019, 9, 1-16. [CrossRef] [PubMed]

70. Korupp, C.; Weberskirch, R.; Müller, J.J.; Liese, A.; Hilterhaus, L. Scaleup of Lipase-Catalyzed Polyester Synthesis. Org. Process. Res. Dev. 2010, 14, 1118-1124. [CrossRef]

71. Wiemann, L.; Nieguth, R.; Eckstein, M.; Naumann, M.; Thum, O.; Ansorge-Schumacher, M.; Ansorge-Schumacher, M.B. Composite Particles of Novozymeâ€ ... 435 and Silicone: Advancing Technical Applicability of Macroporous Enzyme Carriers. Chem CatChem 2009, 1, 455-462. [CrossRef]

72. Ansorge-Schumacher, M.B.; Nieguth, R.; Wiemann, L.O.; Weishaupt, P.; Thum, O.; Eckstein, M. Belastbare Enzympräparate für die technische Biokatalyse. Chem. Ing. Tech. 2010, 82, 35-42. [CrossRef]

73. Keng, P.; Basri, M.; Ariff, A.; Abdulrahman, M.; Salleh, A.; Abdulrahman, R.; Rahman, M.B.A. Scale-up synthesis of lipasecatalyzed palm esters in stirred-tank reactor. Bioresour. Technol. 2008, 99, 6097-6104. [CrossRef] [PubMed] 
74. Paiva, A.; Matias, A.A.; Duarte, A.R.C. How do we drive deep eutectic systems towards an industrial reality? Curr. Opin. Green Sustain. Chem. 2018, 11, 81-85. [CrossRef]

75. Pithani, S.; Karlsson, S.; Emtenäs, H.; Öberg, C.T. Using Spinchem Rotating Bed Reactor Technology for Immobilized Enzymatic Reactions: A Case Study. Org. Process. Res. Dev. 2019, 23, 1926-1931. [CrossRef]

76. Guajardo, N.; Schrebler, R.A.; De María, P.D. From batch to fed-batch and to continuous packed-bed reactors: Lipase-catalyzed esterifications in low viscous deep-eutectic-solvents with buffer as cosolvent. Bioresour. Technol. 2019, 273, 320-325. [CrossRef] [PubMed]

77. Dai, Y.; Witkamp, G.-J.; Verpoorte, R.; Choi, Y.H. Tailoring properties of natural deep eutectic solvents with water to facilitate their applications. Food Chem. 2015, 187, 14-19. [CrossRef] [PubMed]

78. Hayyan, A.; Mjalli, F.S.; AlNashef, I.M.; Al-Wahaibi, Y.M.; Al-Wahaibi, T.; Hashim, M.A. Glucose-based deep eutectic solvents: Physical properties. J. Mol. Liq. 2013, 178, 137-141. [CrossRef]

79. Hollenbach, R.; Bindereif, B.; Van Der Schaaf, U.S.; Ochsenreither, K.; Syldatk, C. Optimization of Glycolipid Synthesis in Hydrophilic Deep Eutectic Solvents. Front. Bioeng. Biotechnol. 2020, 8, 382. [CrossRef] 